\title{
The genus Mallomonopsis
}

\author{
BY KATHARINE HARRIS \\ Botany Department, University of Reading
}

(Received 20 April 1965)

\begin{abstract}
SUMMARY
The genus Mallomonopsis (Chrysomonadales) is discussed and five taxa are described from observations with the electron microscope: M. elliptica, M. elliptica var. salina, M. elliptica var. oviformis (formerly Mallomonas oviformis), $\boldsymbol{M}$. peroneides sp.nov. and $\boldsymbol{M}$. ouradion (formerly Mallomonas ouradion). The two flagella, which distinguish Mallomonopsis from Mallomonas, comprise a stout one with mastigonemes and a slender one which is smooth and has a photoceptor at its base. The silica scales are compared in detail and are shown to differ in construction as well as in appearance in the different species and are considered to provide the only satisfactory basis for specific separation.
\end{abstract}

Mallomonopsis is a genus of free-swimming unicellular flagellates of the Chrysomonadales and found in fresh water. The living organisms look very like those of the long-known Mallomonas and were distinguished by Matvienko in 1941; Lund (1942) recognized it and described it under another name. Since then a few more species have been added to the genus, together with some more morphological information but until recently all the information was obtained with the light microscope.

Mallomonopsis proves to be widespread and must be fairly common and I feel sure was overlooked by many as it certainly was by me. The sole distinction is that it has two unequal flagella and not just one as in Mallomonas. Mallomonopsis has silica scales, usually bearing hinged silica bristles as in Mallomonas. In the present paper I supplement the light microscope observations with electron microscope studies of the scales which have elaborate structure and I have distinguished the different layers that compose them. These silica scales as in other Chrysomonads prove to be of the greatest taxonomic value and it is now realized that it is difficult to distinguish species with any certainty without electron microscope data.

\section{METHODS}

The free swimming organisms were concentrated by a low-speed centrifugation; spores were sometimes obtained by keeping the original collection in a bottle in the light. Concentrates were fixed on a glass slide for 2 min. in osmic tetroxide vapour after which they were dried. When the silica bristles were to be removed the fixed dried organisms of a nearly pure preparation were treated with 6 drops of concn hydrofluoric acid in $50 \mathrm{ml}$. of water for $30 \mathrm{~min}$. on a Formvar-coated slide. The preparation was then mounted on grids for examination in the electron microscope. Crystal violet was used as the flagellar stain when the organisms were 
examined in balsam with the light microscope. To prepare the cells for the electron microscope the fixed dried concentrate on a glass slide was coated with $400 \AA$ carbon and mounted on copper grids in the usual way for direct examination. Very dilute hydrofluoric acid was used in preparing the replicas (3 drops in $50 \mathrm{ml}$. water for $15 \mathrm{~min}$.).

History. Matvienko in 1941 based Mallomonopsis on M. elliptica and M. clavata both from Kharkov, U.S.S.R. Later he added $M$. squamulaeperforata (1949) and $M$. robusta (1952). Lund (1942) described what we now believe is $M$. elliptica as Ochromallomonas pelophila from England. Bourrelli (1960) described $M$. elliptica from the Ivory Coast and Ettl (1960) from Czechoslovakia. Asmund \& Hilliard (1965) describe a variety of $\boldsymbol{M}$. elliptica from Alaska, with electron micrographs. Takahashi (1959) figured (without names) isolated scales which closely resemble $M$. elliptica and $M$. peroneides and in 1960 he figured another under the name Mallomonas oviformis which looks exactly like the scale of Mallomonopsis elliptica var. oviformis. These are all from Japan. The only other species known to me is $M$. deltoides which I suspect may be a few-celled form of Synura.

\section{Mallomonas elliptica Matvienko 1941, Figs. 1-6; Pl. 1, figs. 1-6}

The living organism (Fig. 2) shows concave scales along its sides and most scales carry one bristle. However, there may be three bristles as in Fig. 6, a fixed and dried organism; the electron micrograph, Pl. 1, fig. 2, also shows three. The dried scales (Figs. 4, 5) often show an opaque area towards the distal end. All the scales, whether anterior or from the middle region or posterior end are alike in this species, as indeed they are in its varieties. The cyst (Fig. 3) is round and smooth as in Matvienko's material.

I give an electron micrograph of a nearly complete cell (Pl. 1, fig. 1) which shows the scales strongly overlapping as is usual in this species, but when the organisms swells up before forming a spore there is much less overlap. In direct electron micrographs (Pl. 1, figs. 2, 3) the scale shows a uniformly dense proximal border and most of the scale surface is occupied by a dark network. This network grows denser towards the distal end (in Pl. 1, fig. 2, but less markedly in fig. 3). These electron-dense parts are the opaque regions seen under the light microscope. There is a small hole near the proximal end surrounded by a closer network. In a replica (Fig. 6) the proximal border is now clear but there is a darker region where the border overlaps the scale. The dense network has largely disappeared, but instead each mesh is represented by a little papilla with a thin point at its middle. The proximal hole is conspicuous and it is surrounded by an area with no papillae.

Dimensions of my material: cell 14-34 $\mu \times 8-17 \mu$; scales $4.5-5.5 \times 3.0-4.5 \mu$; cyst 17-22 $\mu$.

Occurrence. Mallomonas elliptica has been found in the neighbourhood of Reading, Berkshire, in a number of ponds and small lakes on a subsoil of shallow acid peat. The localities are usually surrounded by trees but sometimes only a few trees or bushes are present. I have found the species in each month except June but its appearance is always unpredictable by me. I have not found it in large numbers since I was able to avail myself of the electron microscope. 
Mallomonas elliptica var. salina Asmund \& Hilliard (Figs. 17-20; Pl. 2)

This variety is not described here in detail because Asmund \& Hilliard (1965) do so, but I give some points not covered by them. The living organism of the variety is distinguishable by the lens-shaped scales seen along its sides (Fig. 17) and the dried scales (Fig. 18), as they remarked, shown an opaque inner area. Most scales carry one bristle, but I have seen up to three. The cyst (Fig. 20), which was unknown, is smooth, rounded and with a small anterior pore.

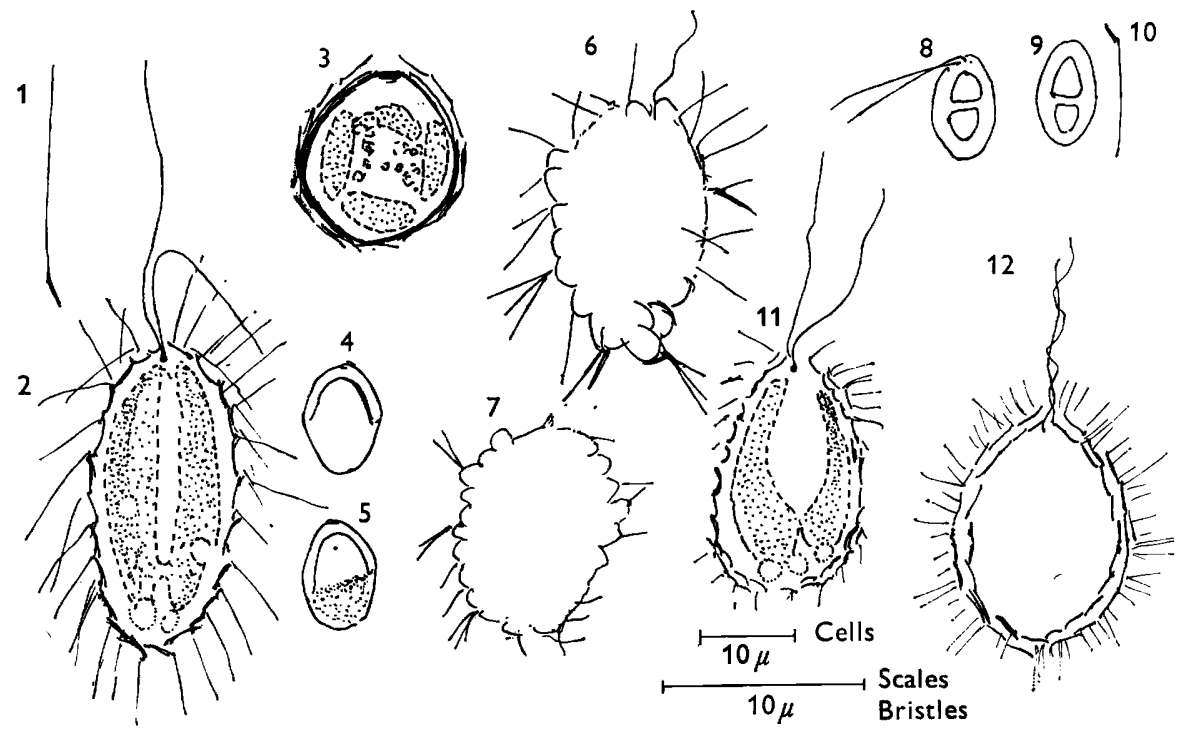

Figs. 1-6, M. elliptica. 1, Bristle; 2, living organism; 3, cyst in mother-cell armour; 4, 5, scales; 6, fixed dried organism showing some bristles in bunches.

Figs. 7-12, M. peroneides. 7, Fixed dried organism showing some bristles in bunches; 8, 9, scales, one with two bristles; 10, bristle; 11, living organism; 12, living organism showing what appear to be two layers of scales.

All complete organisms, $\times 1000$; all scales and bristles, $\times \mathbf{2 0 0 0}$.

In the electron microscope the scales and bristles look just like their figures in direct view (Pl. 2, figs. 9-10) but replicas (Pl. 2, figs. 7, 8) are very different. The strong radiating struts along the proximal margin and the electron-dense network occupying most of the scale surface both disappear. Evidently both are internal features. For some reason the tops of the papillae often appear as open holes in the replica.

Dimensions of my specimens: cell $21-32 \times 16-19 \mu$; scales $5 \cdot 5-6 \cdot 0 \times 3 \cdot 0-3 \cdot 5 \mu$, bristles 7-12 $\mu$; cyst 19-21 $\mu$ wide.

Occurrence. Mallomonas var. salina occurs in winter, spring or summer. It has been found in an old overgrown gravel pit and an overgrown pond on gravel subsoil. I have also found scales in a small lake on old agricultural land and in a pool in woodland near acid peat with Sphagnum growing near. Asmund's original sample was found in brackish water, so the variety is adaptable. 
Mallomonopsis elliptica var. oviformis (Nygaard) comb.nov.

(Figs. 13-16; Pl. 3. figs. 11-14)

Mallomonas oviformis Nygaard, 1949

Mallomonas oviformis Nygaard. Asmund, 1959

Mallomonas oviformis Nygaard. Harris \& Bradley, 1960

The first two of the above descriptions relied on the light microscope alone, but in the third the electron microscope was also used. I have now found that there are two flagella; they can be seen in living organisms, in stained organisms mounted in Canada balsam and in electron micrographs.

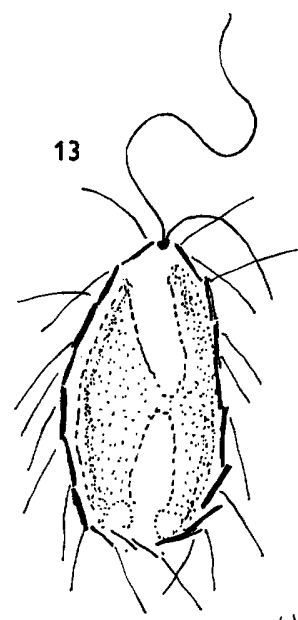

15
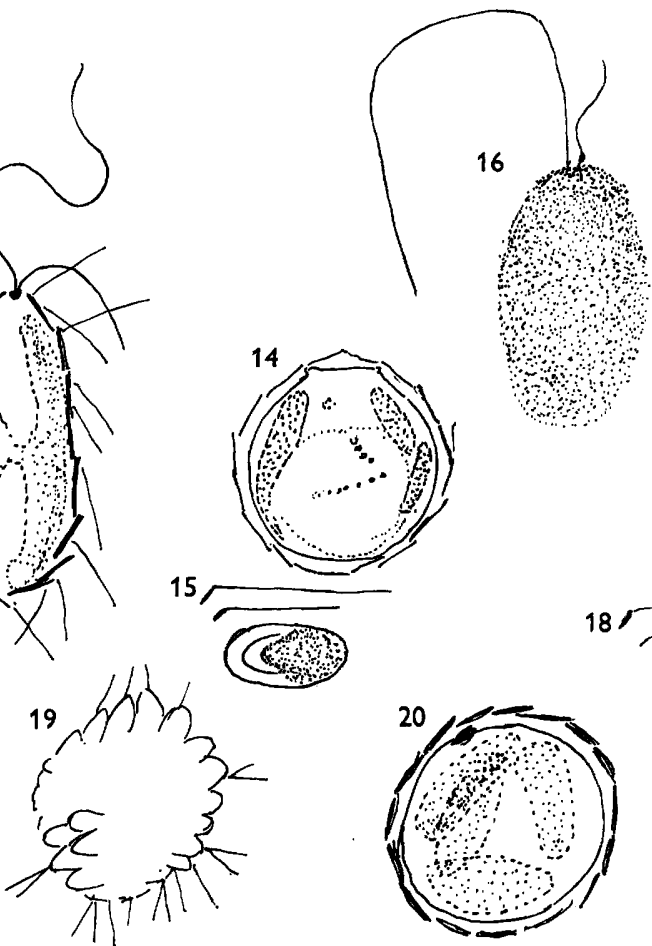

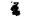
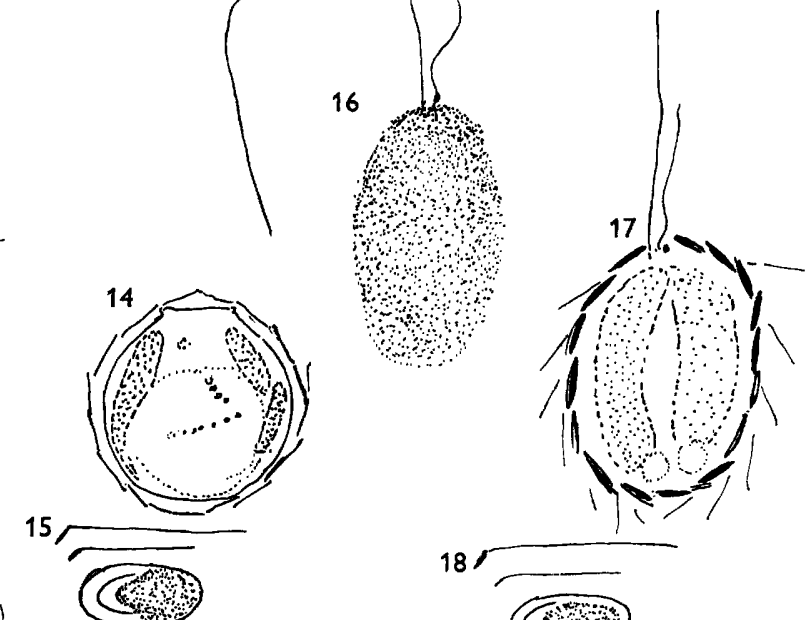

18
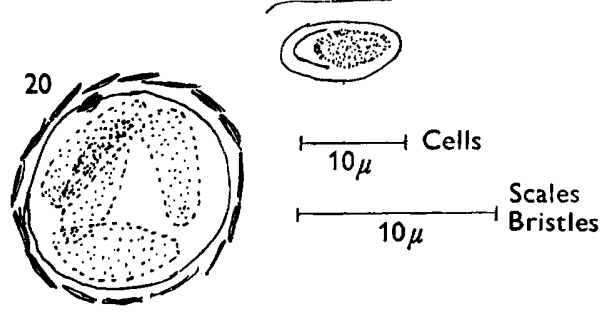

Figs. 13-16, M. var. oviformis. 13, Living organism; 14, cyst in mother-cell armour; 15, two bristles and a scale; 16, cell stained and mounted in Canada balsam showing two flagella and flagellum-swelling.

Fig. 17-20, M. var. salina. 17, Living organism; 18, two bristles and a scale; 19, fixed dried organism showing bunches of bristles; 20, cyst in mother-cell armour.

All complete organisms, $\times 1000$; all scales and bristles, $\times 2000$.

In the variety oviformis the scales look like flat plates along the sides of the organism (Fig. 13). The dry scale (Fig. 15) has a proximal rim, then a small clear area and a large opaque area occupying the middle and distal parts. Each scale commonly bears one bristle, but these may be two or even three. The cyst, which has not been seen previously, is smooth and round with a small pore in a wide saucer-shaped rim. 
In a direct electron microscope examination, a scale (Pl. 3, fig. 14) showed a dense proximal border not crossed by any darker struts. Next to this is a less dense area and then a large part of the scale shows a very complex pattern. I consider that this is made up of three superimposed patterns, each belonging to a different layer. First, there is an inner layer with tiny holes, regularly spaced over the whole surface; this layer alone is seen near the thick rim in Pl. 3, fig. 14. Then over most of the surface is a middle layer with a pattern of dark curved bars, but these are absent near the margins. Finally, on top of this is a layer with prominent dark papillae but these do not extend to the distal margin (Pl. 3, fig. 11).

A few scales are simpler and I believe immature and have fewer layers; Pl. 3, fig. 12, shows one of these. It must already be external because it bears two bristles but it consists of the margin and the basal perforated layer alone (Pl. 3, fig. 12). Another unusual scale is seen in Pl. 3, fig. 13, where just a small part of the outer layer is missing and the curved bars are exposed.

Dimensions of my material: cell 18-42 $\mu \times 11-19 \mu$; scales $5-6.5 \mu \times 3-3.5 \mu$, bristles 8-12 $\mu$; cyst typically $18 \times 20 \mu$, diameter range $16-13 \mu$.

Occurrence. Variety oviformis is sometimes met in enormous numbers in ponds on agricultural land from November to March; I also found a few in one pond on a thin acid peat. In some years $I$ found none at all, but in 1965 it grew very well and appeared in ponds where $I$ had not previously seen it. As a rule it encysts when the weather becomes warm; but in one pond, while many encysted in late January, large numbers of motile organisms continued in the water until late March.

Discussion and comparison of the varieties. The three distinct taxa here described as Mallomonopsis elliptica and its two varieties all agree equally well with Matvienko's drawing, for this did not show the small differences which distinguish them under the light microscope. These differences are in the scales; what I take as type elliptica has scales which look concave in profile; variety oviformis has flat scales and variety salina convex lens-shaped scales. The isolated dried scales can often be distinguished by the position of the opaque area, in the elliptica it is small and limited to the distal end; in salina it is in the middle region, and in oviformis it is large and extends nearly to the proximal end. The electron microscope makes these differences more definite.

As I have said, there is nothing to show which should have the name Mallomonopsis elliptica but current practice has settled it. Bourrelly gave figures of what he identified as $M$. elliptica and these figures show the opaque area mentioned above; others have assumed he was right and have followed him in regarding his account as an amplified description of the type. I have included the three taxa in the one species because they are very similar indeed and even electron micrographs of the scales have many features in common. It is in the deeper layers of the scales that the main differences lie and these are clearly revealed by direct electron micrographs.

Mallomonopsis peroneides sp.nov. (Figs. 7-12; Pl. 4, figs. 15-21)

Latin diagnosis. Cellula rotundata ovoides, setis brevibus et teneribus ubique contecta, nonnunquam setis absentibus. Squamae ellipticae, margine lato et crasso vallum fabricante per medium squamae et foveas duo formante. Pars 
proximalis marginis laevis, tignis intus instructa; residuum squamae foraminibus multis et papillis dispersis ornatum, sed papillae paucae in cavo proximali. Pars distalis marginis in exteriore parte scrobiculum exiguum rotundatum ferens, prope commissuram setarum. Setae una vel duo vel tres per squamam, tenues laeves non attenuatae sed apex acumitatus ipse saepe alterum ferens apicem acuminatum subtiliorem. Cystum ignotum.

Dimensions. Cellula 11-13 $\times 11-26 \mu$, squamae $c .3 \times 5 \mu$, setae 6-8 $\mu$.

English diagnosis. Cell round ovoid covered all over with short slender bristles which may sometimes be absent. Scales oval with a broad thick margin an extension of which forms a ridge across the middle of the scale leaving two depressions. Proximal part of margin smooth with internal struts. Rest of scale covered with perforations and scattered papillae, the papillae, however, are infrequent in the proximal depression. Distal margin has small circular depression on the outer side near point of insertion of bristles. Bristles, one to three per scale, short, slender, smooth, not tapering but bearing at the tip a small needle-shaped point which may in turn bear a second finer needle-shaped point. Cyst not known.

The name peroneides, meaning like a buckle, refers to the appearance of the scale.

Description. This small and inconspicuous organism is usually covered with fine bristles (up to three to a scale) but is sometimes without bristles. Often the cell looks as though clothed in two or three layers of scales (Figs. 11, 12) but this may be an effect of strong overlap. The flagella were nearly equal in the few organisms where they were seen. The scales were studied as direct electron micrographs, as replicas of both sides, and as direct electron micrographs after some but not all of the silica had been removed.

Plate 4, fig. 20, shows a scale in a direct micrograph. The dense parts are too dark to show details but the pattern over the rest of the scale is seen. This consists of two superimposed patterns; the first a uniform layer showing regularly spaced minute pores or pits seen as pale spots, the second a pattern of dark spots which are papillae. Plate 4, fig. 21, shows a small misshapen scale with similar marks; it probably comes from one or other end of the cell. A replica of the inner surface (Pl. 4, fig. 15) is nearly smooth but shows the minute pores as inconspicuous pits. A replica of the outer surface ( $\mathrm{Pl}$. 4, fig. 16) shows the strong transverse bar and the papillae over the greater part of the surface. Plate 4, fig. 19, shows a scale which has been partly dissolved with dilute hydrofluoric acid; here some of the scale has vanished entirely and most of its surface has gone. The papillae are seen as black rings and the proximal flange is now transparent enough to show its radiating struts which evidently are internal.

Occurrence. Mallomonopsis peroneides occurred in the shallow, swampy end of an artificial lake in a forest Benyon's Enclosure (Grid ref. $628 \mathrm{E} / 633 \mathrm{~N}$ ). It was only found in small numbers, in August 1959.

Mallomonopsis ouradion (Harris \& Bradley) comb.nov. (Pls. 5-7)

Mallomonas ouradion Harris \& Bradley, 1958

New observations showed that this species has two flagella and must therefore be transferred to Mallomonopsis. The new material agreed precisely with that previously described except that a larger range of size was noted, the motile 
organism is $11-33 \times 11-21 \mu$. Further observations were made on the scales. The living organism often looks as though it has more than one layer of scales, but as in other species I suppose that this is an optical effect caused by great overlap of one layer of scales. I have not seen signs of more than one layer in electron micrographs. The extent of overlap varies; in Pl. 5, fig. 24, about three-quarters of each scale was overlapped, but in a similar electron micrograph of another organism only a quarter of each scale was overlapped.

The structure of the scales is now better understood; this is of value for comparison with other species. The scale is here simpler. It consists of a single delicate layer of perforated silica on to which various ridges and ornamentations are later developed externally. There is no middle layer. In Pl. 6, fig. 27, the scale marked ' $b$ ' (at the bottom right) has only the delicate basal layer. It is one of the incompletely silicified scales of the kind I call 'immature'. The scales on the left, particularly the one on the top left marked ' $a$ ' shows the mature structure. Various electron-dense parts have been added, including the dark papillae over its surface. I have also seen bristles which I would describe as immature; their apices are composed of spongy silica and without a sharply defined margin. We do not yet have information how the scales of Mallomonopsis or Mallomonas are formed, but whatever the mechanism it is one which rather often ceases before the scale is fully silicified. A diffraction pattern of the scales of $M$. ouradion was examined, but it showed the pattern of amorphous silica only, so it would appear that all parts of the scale are made of this one material.

\section{Flagella}

Since the flagella characterise Mallomonopsis they merit further description. One flagellum, the stout one (with mastigonemes), is generally easy to see in the living organism. It usually points forwards. The other, which is smooth, may be rather longer or rather shorter but is always much more slender and it points in varied directions, but it does not seem to act as a trailing flagellum as in some flagellates. It is sometimes difficult to see because it is hidden among the fine silica bristles; this difficulty applies equally to the optical and the electron microscope. However, I have seen both flagella repeatedly in living organisms of four of the five kinds described here. The remaining one Mallomonopsis ouradion first showed the smooth flagellum under the electron microscope, but I did not see them both in the living organism, even though I examined large numbers.

Fully convincing views of both flagella can be seen in fixed organisms of all kinds when these are stained with a suitable stain and mounted in Canada balsam; then the silica bristles become nearly invisible and no longer confuse the picture (Pl. 5, figs. 22 and 23).

An electron micrograph of the flagella of a de-silicified cell of Mallomonopsis ouradion is shown in Pl. 7, fig. 29. It was taken chiefly to show the photoceptor or flagellum swelling at the base of the smooth flagellum. This has not been figured before with the electron microscope. Lying as it does within the top ring of scales it can only be seen on a de-silicified organism. The flagella resemble the flagella of Synura very closely and even have small points on the ends of the mastigonemes. These points are not shown here; but Mr D. E. Bradley informs me that he has seen them in Synura. The smooth flagellum, however, has certain differences. It 
has the normal core at the base, but often tapers to a single strand at the free end. It is very fragile (unlike that of Synura) and easily breaks up on treatment.

\section{CONCLUSIONS}

It is likely that further species at present in Mallomonas may have to be transferred to Mallomonopsis. Once I began to search specifically for a second flagellum, I found it in two forms I had previously described as having one. One of these forms first showed the smooth flagellum in electron micrographs and then in stained preparations; but I never saw it in the live state. Then it is plain that while the species and varieties distinguished here can, with more or less reliability, be distinguished with the optical microscope, once their scales are examined with the electron microscope specific characters of another order of reliability emerge. It is indeed difficult to see how determinations based solely on the optical microscope will eventually be accepted alongside those with electron microscope details.

The taxonomic position of Mallomonopsis in relation to Mallomonas needs to be examined, but for this we need information not yet available. Bourrelly (1957) puts the two close together in his Synuraceae and the present work, as far as it goes, supports his conclusion, for it agrees with Synura very closely in its flagella. The position of Mallomonopsis close to Mallomonas is also supported since the two are similar in everything but their flagella.

I wish to thank Professor R. W. Ditchburn, F.R.S., and Dr T. Evans for allowing me to use the electron microscope in the J. J. Thomson Physical Laboratory, The University, Reading, Mr F. Robertson for translating my diagnosis into Latin, Dr R. W. A. Park for help with staining the preparations for the light micrographs, and Miss B. Asmund for allowing me to see her manuscript on Mallomonas elliptica var. salina.

\section{REFERENCES}

Asmund, B. (1959). Electron microscope observations on Mallomonas species. Ark. Dansk Bot. 18, 3.

Asmund, B. \& Hiluinard, D. K. (1965). Studies on Chrysophyceae from some ponds and lakes in Alaska. IV. Occurrence of a Mallomonopsis species in brakish waters. Hydro biologia, 26, 521.

BourRelly, P. (1957). Recherches sur les Chrysophycées. Rev. algol. Memoire Ser. $1,182$.

Bourrelyy, P. (1960). Quelques observations sur un Mallomonopsis (Chrysophyceae) de Côte-d'Ivoire. Note. C. r. hebd. Séanc. Acad. Sci., Paris, 251, 1898.

Erru, H. (1960). Die Algenflora des Schönhengstes und seiner Umgebung. Nova Hedroigia, 2, 509.

Harris, K. \& Bradley, D. E. (1958). Some unusual Chrysophyceae studied in the electron microscope. J. gen. Microbiol. 18, 71 .

Harris, K. \& Bradley, D. E. (1960). A taxonomic study of Mallomonas. J. gen. Microbiol. 22, 750.

Lund, J. W. G. (1942). Contributions to our knowledge of British Chrysophyceae. New Phytologist, 41, 286.

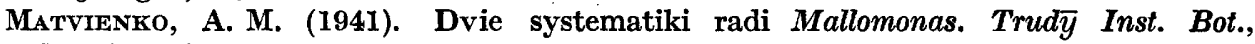
Khar'kiv, 4, 41.

Matvienko, A. M. (1949). De specie nove generis Mallomonopsis Matvienko. Not. syst. sect. cryptog. inst. bot. nom. Komarov. Acad. Sci. 6, 17. 
Journal of General Microbiology, Vol. 42, No. 2

Plate 1
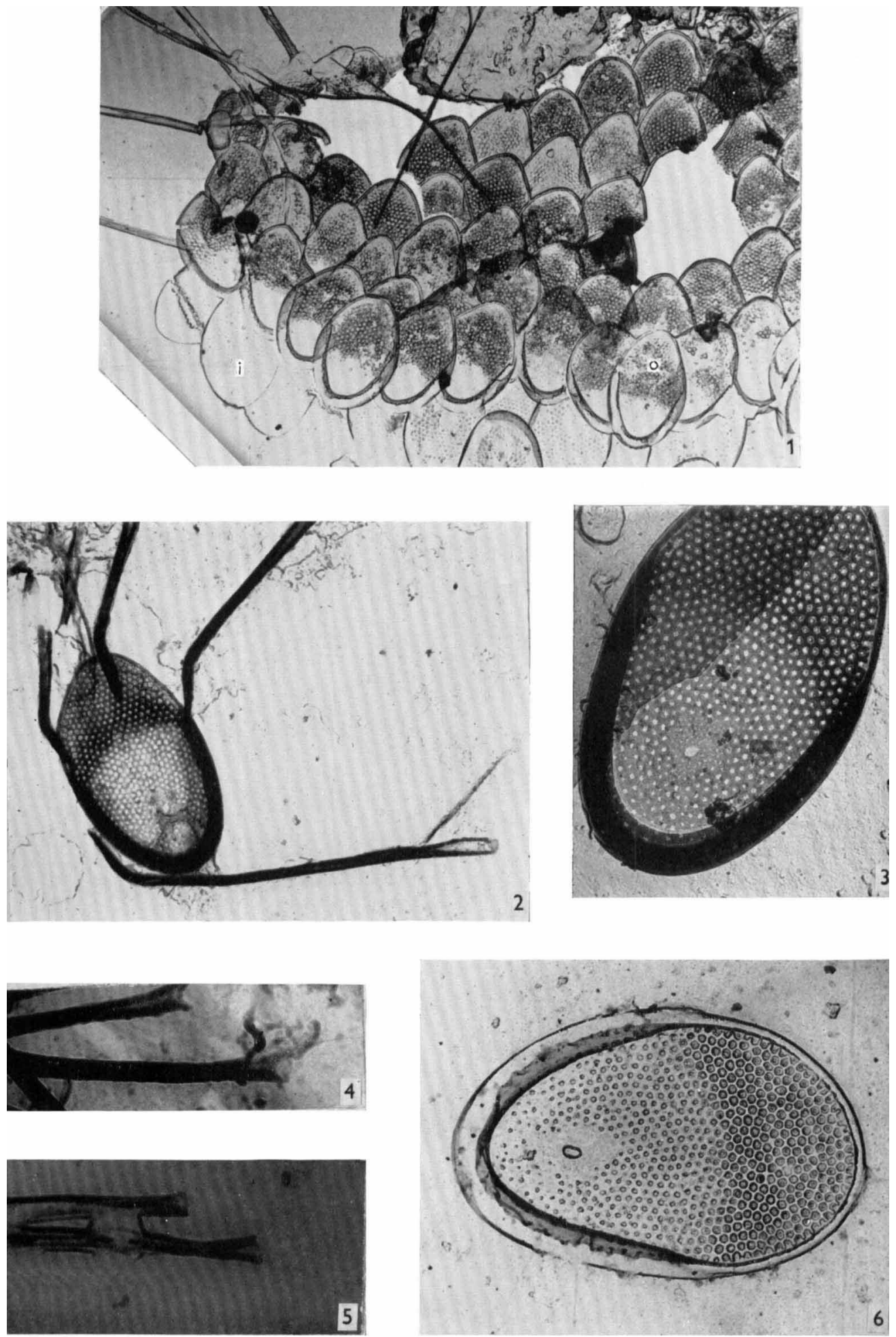

K. HARRIS

(Facing p. 182) 

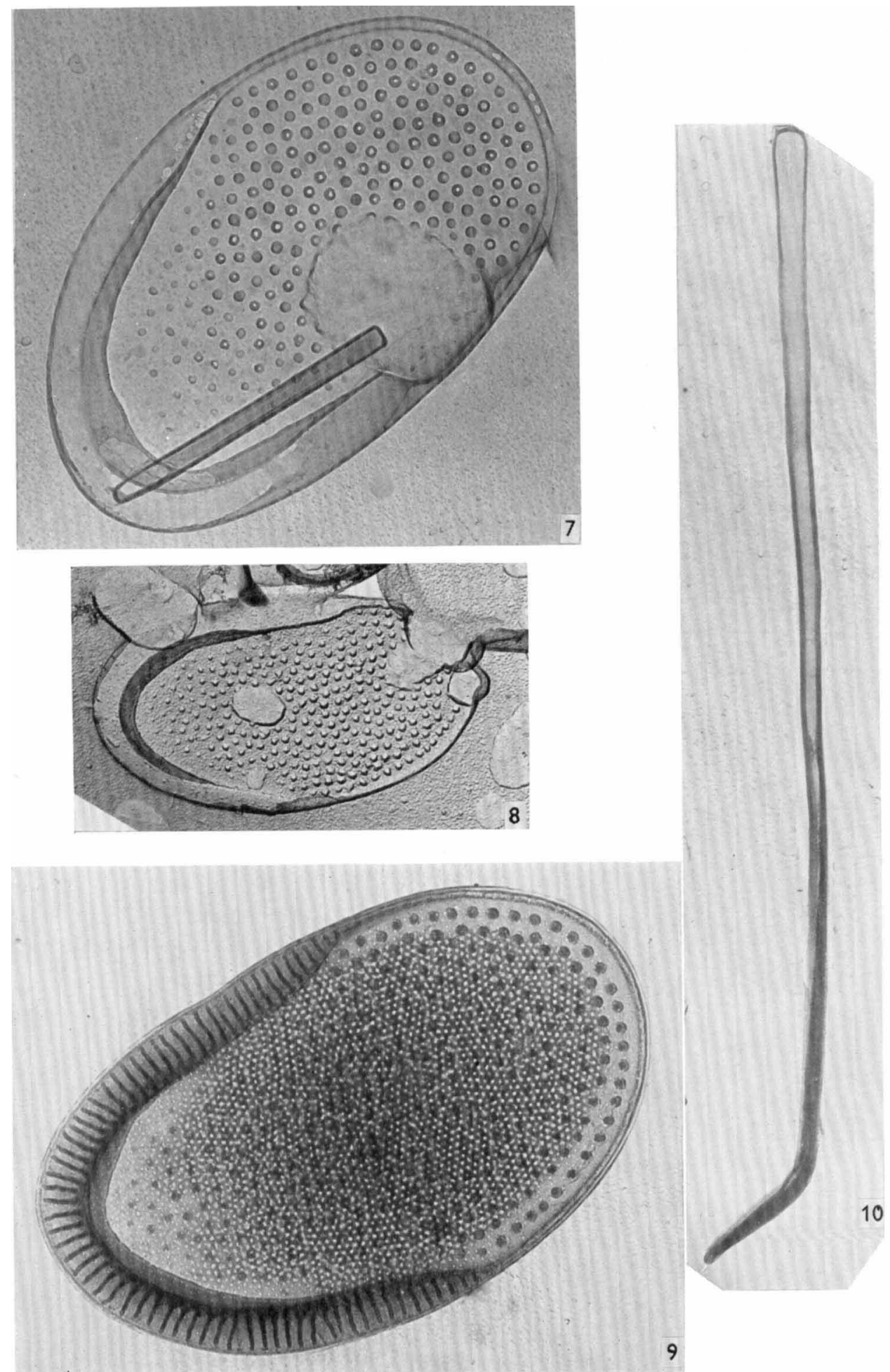

K. HARRIS 
Journal of General Microbiology, Vol. 42, No. 2

Plate 3
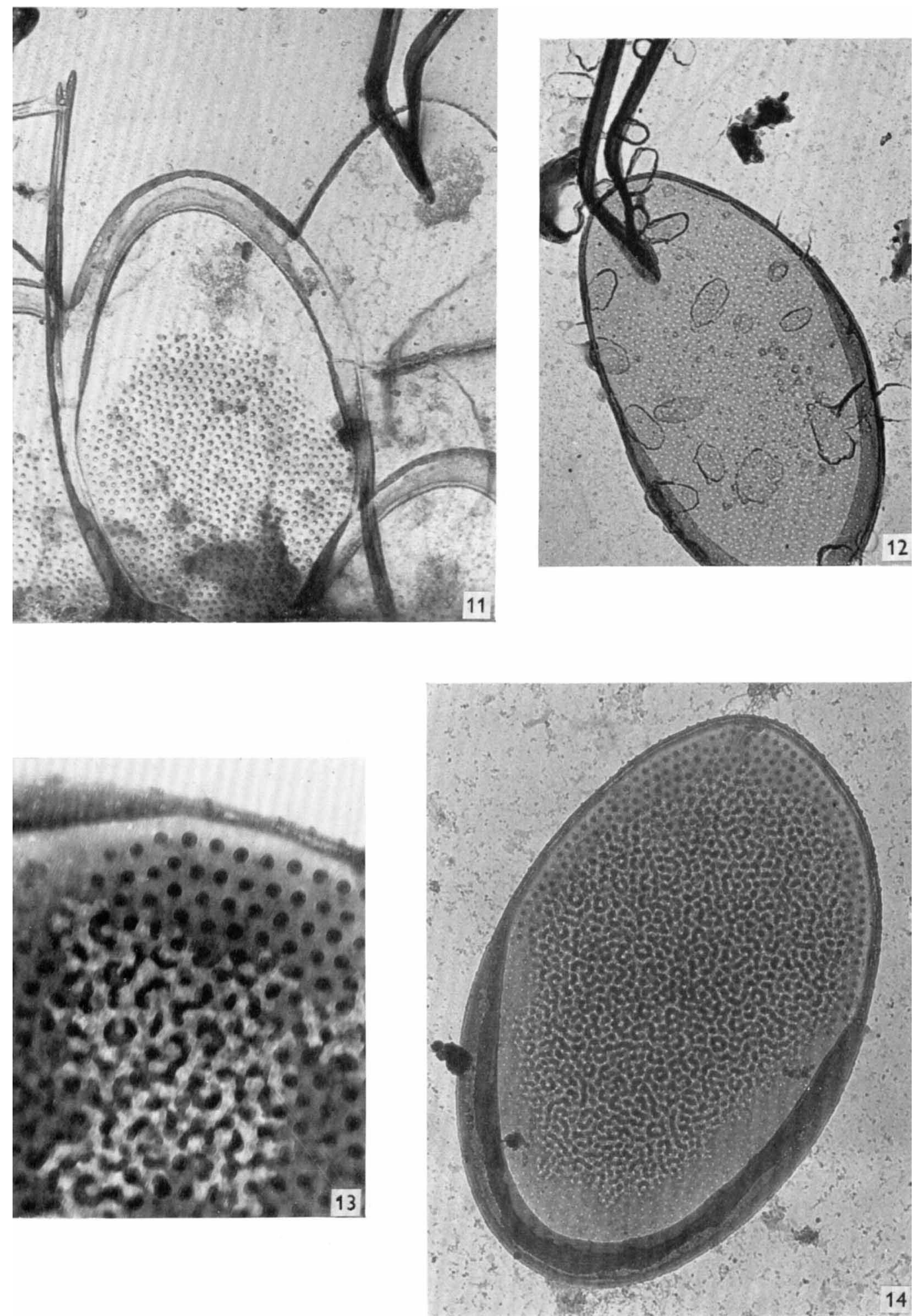
Journal of General Microbiology, Vol. 42, No. 2

Plate 4
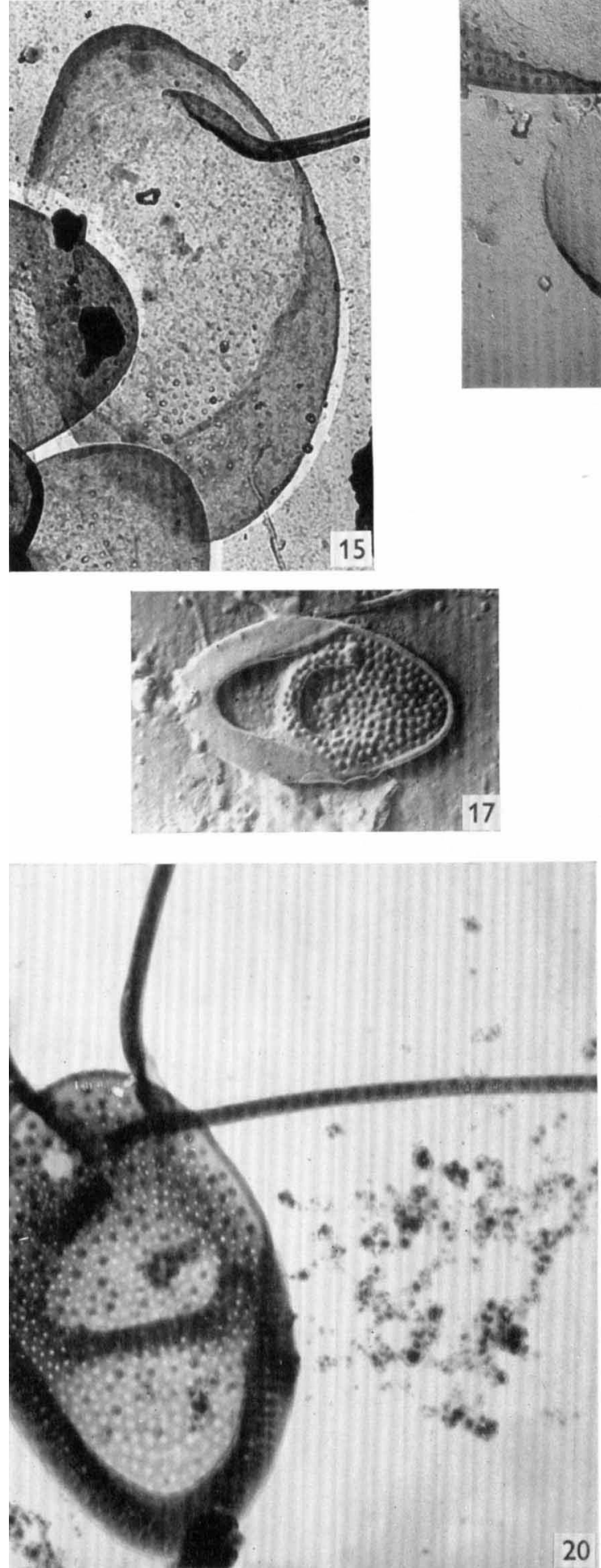
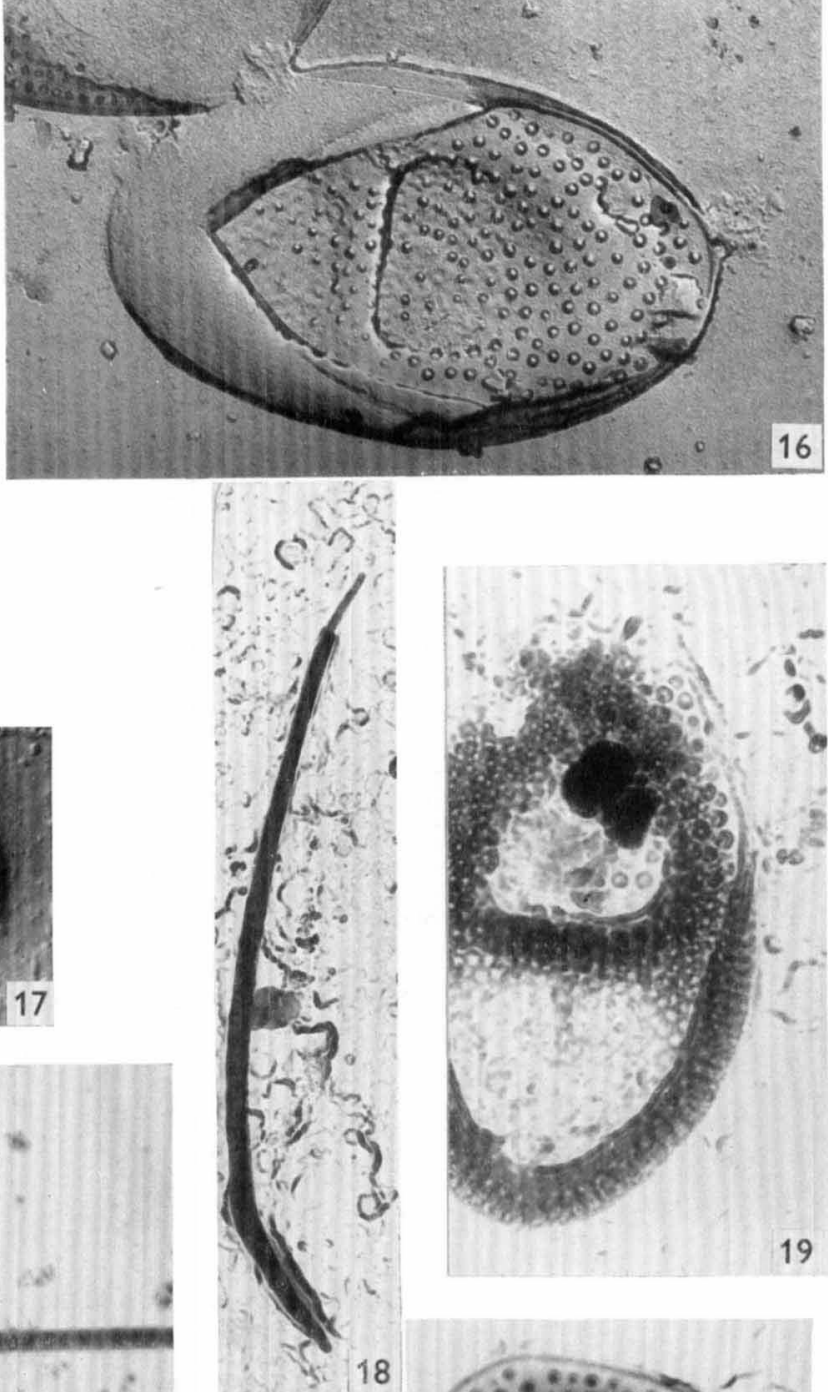

19

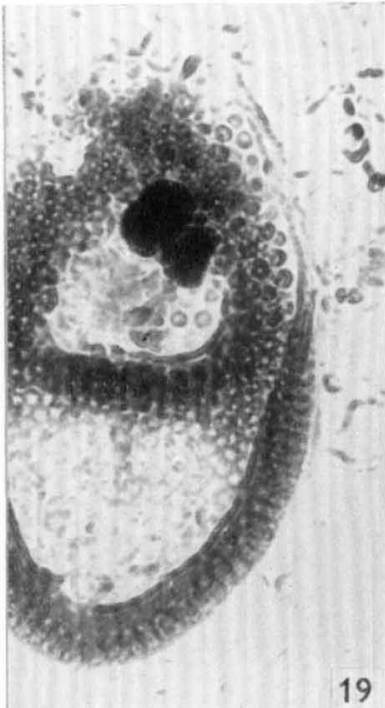

K. HARRIS 
Journal of General Microbiology, Vol. 42, No. 2

Plate 5
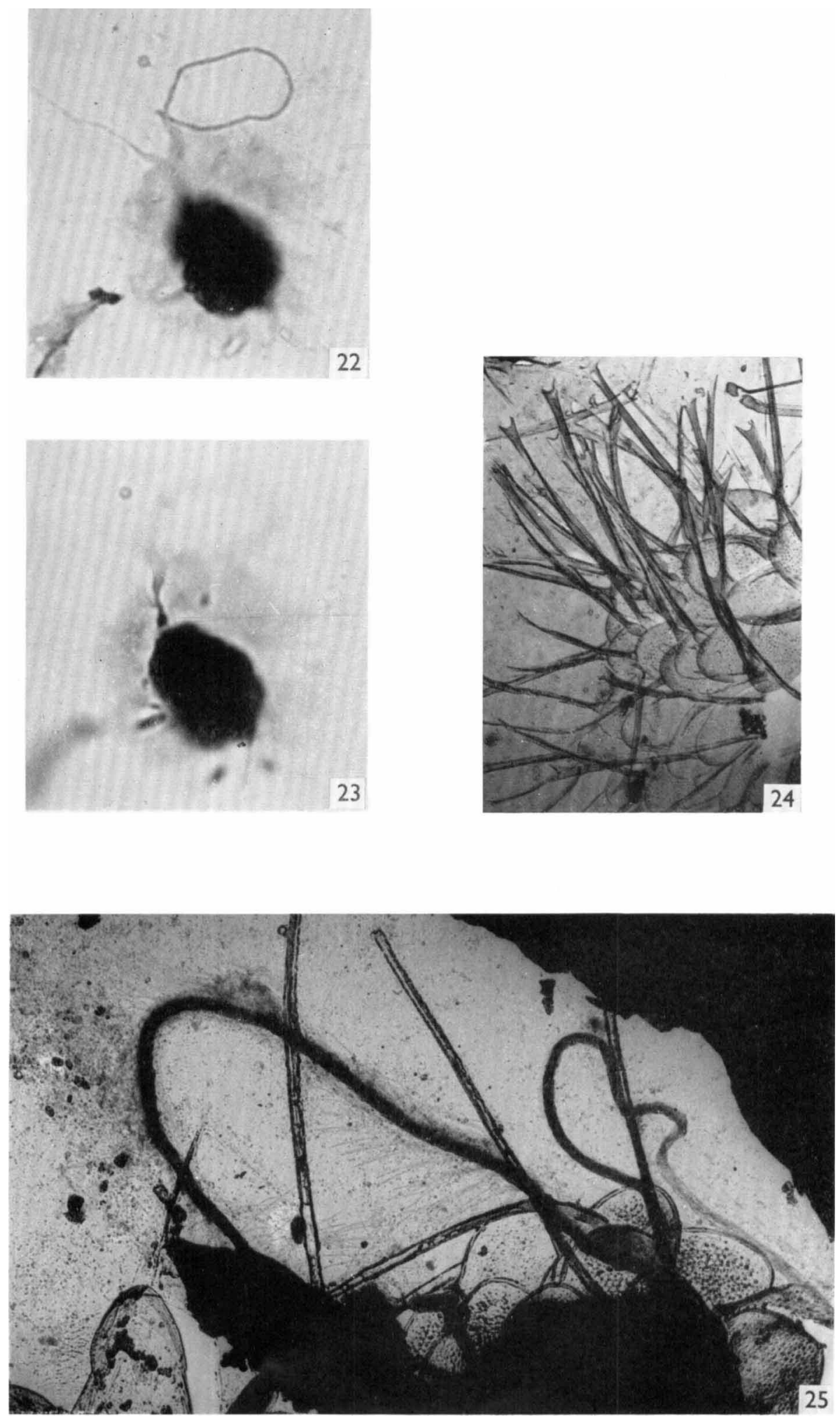

K. HARRIS 
Journal of General Microbiology, Vol. 42, No. 2

Plate 6
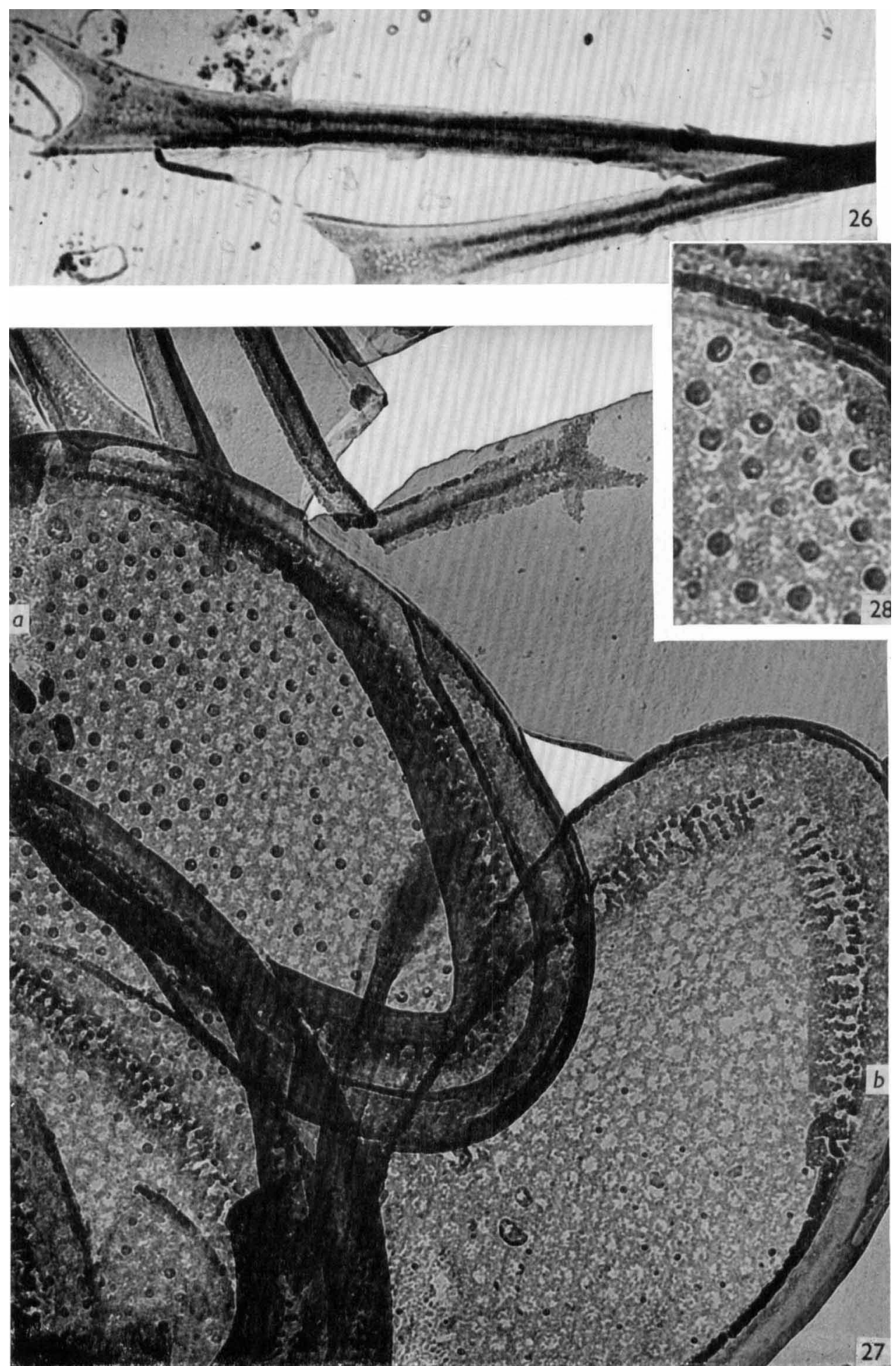

K. HARRIS 
Journal of General Microbiology, Vol. 42, No. 2

Plate 7

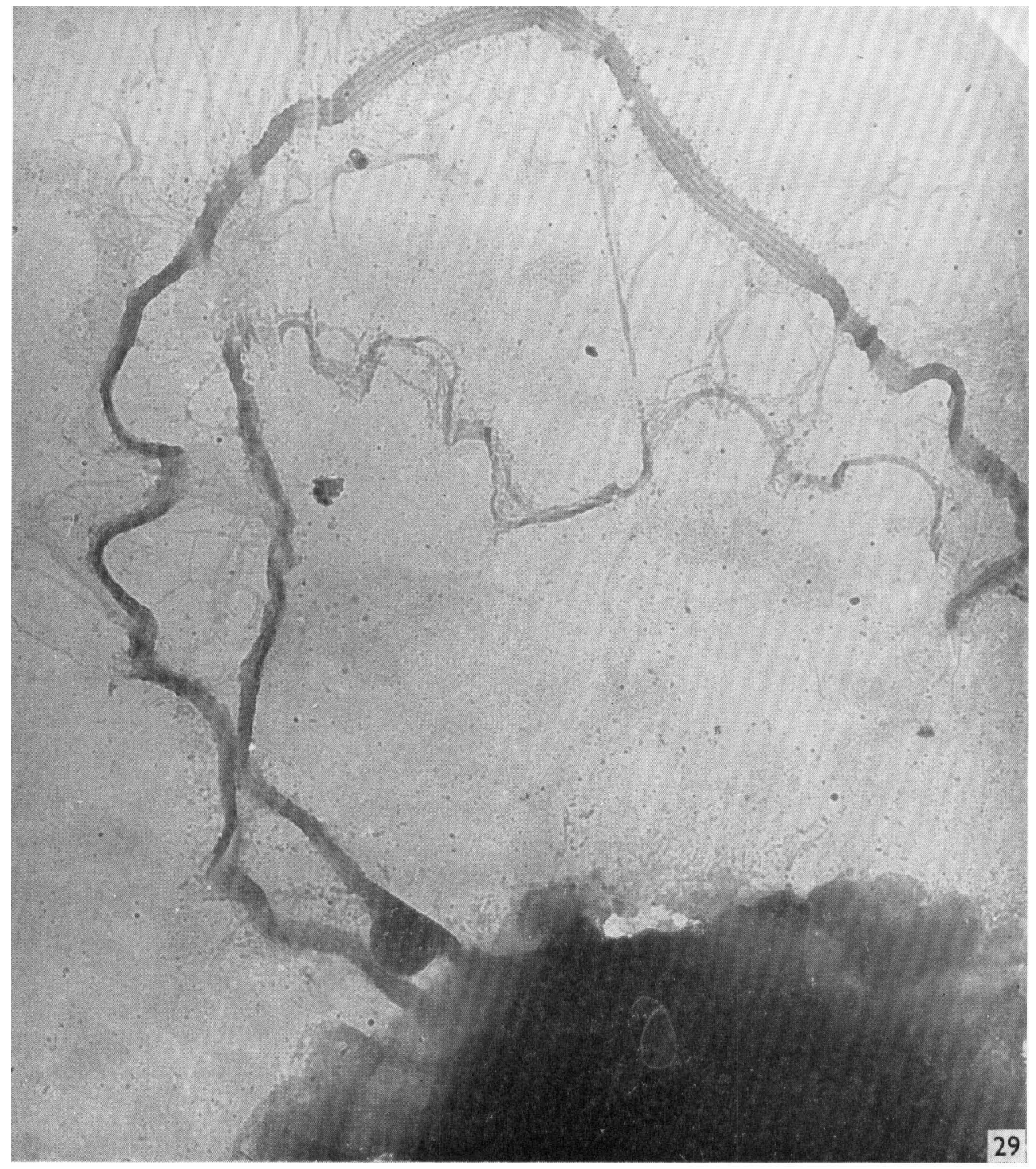

K. HARRIS 

Matvienko, A. M. (1952). Chrysomonadineae e viciniis urbis Charkov. Not. syst. sect. cryptog. inst. bot. nom. Komarov. Acad. Sci. 8, 16.

NygaARd, G. (1949). Hydrobiological studies on some Danish Ponds and Lakes, II. Biol. Skr. 7, 123.

TAkahashi, E. (1959). Studies on genera Mallomonas, Synura and other plankton genera in fresh-water by the electron microscope. I. Bull. Yamagata Univ. (Agric. Sci.) p. 117.

TAKAHASH, E. (1960). Studies on genera Mallomonas, Synura and other plankton genera in fresh-water by the electron microscope. II. Bull. Yamagata Univ. (Agric. Sci.) p. 25.

\section{EXPLANATION OF PLATES \\ Plate 1 \\ Mallomonopsis elliptica Matvienko}

Fig. 1. Replica of part of the armour of an organism showing the inner and outer surfaces of the scales. $\times 4000$. 0 , Outer surface; $i$, inner surface.

Fig. 2. Direct electron micrograph of a scale bearing three bristles. One complete unattached bristle below the scale. $\times 8000$.

Fig. 3. Direct electron micrograph of a scale. $\times 16,000$.

Fig. 4. Free end of a bristle showing a proliferating forked tip. Part of another bristle is above it. $\times 32,000$.

Fig. 5. The free end of two bristles with truncated tips. $\times 32,000$.

Fig. 6. Replica of scale. $\times 12,000$.

Plate 2

Mallomonas elliptica var. salina

Fig. 7. Replica of a scale. $\times 20,000$. (The circular patch and the rod do not belong.) The apex of most papillae is intact.

Fig. 8. Replica of a scale. $\times 12,000$. The apices of all the papillae are broken.

Fig. 9. Direct electron micrograph of a scale. $\times 20,000$.

Fig. 10. Direct electron micrograph of a bristle. $\times \mathbf{2 0 , 0 0 0}$.

\section{Plate 3}

Mallomonopsis elliptica var. oviformis

Fig. 11. Replica of a group of scales with the outer side showing papillae and the inner side of one scale showing two bristle attachments. A forked bristle tip is seen on the left. $\times 16,000$.

Fig. 12. Direct electron micrograph of an immature scale with the base of two bristles. $\times 12,000$.

Fig. 13. Direct electron micrograph of part of a scale from which some of the outer surface has broken away, showing the interior structure. $\times \mathbf{5 0 , 0 0 0}$.

Fig. 14. Direct electron micrograph of a scale. $\times \mathbf{2 0 , 0 0 0}$.

Plate 4

\section{Mallomonopsis peroneides}

Fig. 15. Replica of the inner surface of a scale and the foot of a bristle. $\times \mathbf{1 6 , 0 0 0}$.

Fig. 16. Shadowed replica of a scale (outer side). $\times 16,000$.

Fig. 17. Shadowed replica of a scale made by Miss D. Chessor (A.E.I.). Reversed print by Bradley's method. $\times \mathbf{8 0 0 0}$.

Fig. 18. Direct electron micrograph of bristle. $\times 16,000$.

Fig. 19. Direct electron micrograph of a scale from which the surface silica had been removed. $\times 16,000$.

Fig. 20. Direct electron micrograph of a scale with the base of three bristles. $\times 16,000$.

Fig. 21. Direct electron micrograph of a scale from either the rear or anterior end of the organism. $\times 16,000$. 


\section{Prate 5}

Mallomonopsis ouradion, figs. 22-24

Fig. 22. (Light microscope.) Organism stained with crystal violet, showing the two flagella $\times 1500$.

Fig. 23. (Light microscope.) Same organism as fig. 21 in different focus showing flagellum swelling (photoceptor). $\times 1500$.

Fig. 24. Replica of part of an organism with strongly overlapping scales. $\times 3000$.

Fig. 25. Mallomonas elliptica Matvienko, electron micrograph of the flagella. $\times 4000$.

\section{Plate 6}

Mallomonopsis ouradion

Fig. 26. Direct electron micrographs of two bristle tips. $\times 26,000$.

Fig. 27. Direct electron micrograph of group of scales. $\times 26,000, a$, Mature scale; $b$, immature scale.

Fig. 28. Direct electron micrograph of part of scale. $\times \mathbf{5 2 , 0 0 0}$.

\section{Plate 7}

\section{Mallomonopsis ouradion}

Fig. 29. Direct electron micrograph of two flagella after removal of scales and bristles. $\times 12,000$. A large flagellum swelling is seen near the base of the smooth flagellum. The distal part of the smooth flagellum has been damaged during the preparation of the material. 